\title{
SURVEI KESIAPAN DAN KEPUASAN MAHASISWA TERHADAP LAYANAN PROSES PEMBELAJARAN DALAM JARINGAN UNIVERSITAS TERBUKA SAAT PANDEMIC COVID 19
}

Keywords: online learning, online learning readiness, satisfaction, pandemic, COVID-19 


\section{PENDAHULUAN}

Pada awal tahun 2020, semua negara termasuk Indonesia mengalami masalah kesehatan akibat Corona Virus Disease (COVID) atau penyakit yang disebabkan oleh virus Corona. Penyakit baru ini kemudian dikenal sebagai COVID-19 oleh Badan Kesehatan Dunia/World Health Organization (WHO). Dalam waktu yang sangat singkat jumlah penderita COVID-19 terus berkembang secara signifikan hingga telah menjadi pandemi di seluruh dunia. Menurut laporan WHO per tanggal 31 Maret 2020, penyakit ini telah menyebar dan terpapar di 204 negara dengan jumlah kematian lebih dari 33 ribu manusia. Khusus di Indonesia sendiri penderita Covid-19 terus bertambah dan telah merebak hampir di seluruh propinsi sejak dinyatakan telah menginfeksi Indonesia pada bulan Februari 2020.

Akibat penyebaran COVID-19 yang sangat cepat di Indonesia, Pemerintah, khususnya Menteri Pendidikan dan Kebudayaan melalui Surat Edaran Nomor 36962/MPK.A/HK/2020 tertanggal 17 Maret 2020, mengeluarkan kebijakan tentang pembelajaran secara dalam jaringan (Daring). Disamping itu, surat edaran tersebut juga berisi kebijakan baru terkait Bekerja dari Rumah (BDR) dalam rangka peningkatan kewaspadaan pencegahan penyebaran COVID-19. Menindaklanjuti surat edaran tersebut, selanjutnya Direktur Jenderal Pendidikan Tinggi telah menerbitkan Surat Edaran Nomor 262/E.E2/KM/2020 tanggal 23 Maret 2020 tentang Pembelajaran selama Masa Darurat Pandemi COVID-19. Dirjen Dikti menghimbau seluruh perguruan tinggi untuk menyelenggarakan aktivitas bekerja dari rumah (work from home - WfH) dan para mahasiswa agar belajar dari rumah (study from home-SfH). Tujuan dari pemberlakuan kebijakan WfH dan SfW tersebut dimaksudkan untuk membantu upaya pemerintah dalam menahan laju pertumbuhan wabah COVID-19.

Ketentuan WfH dan SfH memberikan dampak yang luar biasa kepada perguruan tinggi tatap muka yang tidak terbiasa menyelenggarakan proses pembelajaran dalam jaringan (online). Mencermati dan mempertimbangkan keadaan tersebut, Universitas Terbuka berupaya membantu perguruan tinggi lain menyediakan bantuan pembelajaran online (Daring) bagi perguruan tinggi yang memerlukan platform untuk melakukan pembelajaran daring. Bantuan pembelajaran disediakan melalui platform Learning Management System (LMS) dengan alamat https://lms.ut.ac.id. Disamping itu, UT juga telah menyiapkan alternatif layanan pembelajaran yang lain dalam masa pencegahan penyebaran COVID-19; layanan yang diberikan UT pada masa WfH dan SfH antara lain adalah menyediakan pembelajaran dalam jaringan untuk seluruh mahasiswa Indonesia, baik mahasiswa UT maupun non UT. Selanjutnya, sejalan dengan arahan yang disampaikan oleh Kementerian Riset, Teknologi/ Badan Riset dan Inovasi Nasional, UT disarankan agar melakukan pengkajian terhadap penyelenggaraan pembelajaran secara online tersebut. Pembelajaran online yang saat ini dilaksanakan secara sangat masif oleh seluruh perguruan tinggi menjadi perhatian sendiri baik bagi mahasiswa, guru (dosen), serta pihak Pemerintah. Hasil penelitian ini diharapkan dapat memberikan masukan kepada pemerintah dan pihak terkait lainnya dalam pengambilan keputusan.

Berangkat dari kondisi dan arahan Pemerintah tersebut, penelitian ini dilaksanakan untuk mengkaji kaktor faktor apa saja yang mempengaruhi tingkat kesiapan dan kepuasan mahasiswa terhadap layanan proses pembelajaran online di UT? Disamping itu, melalui penelitian ini juga ingin digali bagaimanakah tingkat kesiapan dan kepuasan mahasiswa terhadap kualitas layanan proses pembelajaran online di UT tersebut? Peneliti melihat bahwa kedua isu tersebut merupakan isu strategis yang akan berpengaruh bukan hanya terhadap kualitas layanan pembelajaran secara dalam jaringan sebagai moda baru bagi beberapa mahasiswa konvensional tetapi juga terhadap kesuksesan belajar mahasiswa. 


\section{KAJIAN LITERATUR}

\section{A. Pengertian Pendidikan Tinggi Jarak Jauh}

Sistem belajar jarak jauh ditandai dengan adanya keterpisahan antara tenaga pengajar dengan mahasiswanya serta penggunaan beragam media dalam proses pembelajaran untuk menjembatani keterpisahan tersebut (Wedemeyer, 1981). Secara lebih lengkap Keegan (2005) menegaskan bahwa ada enam ciri utama sistem belajar jarak jauh yaitu: (1) Terpisahnya antara pengajar dan yang diajar; (2) Adanya pengaruh dari suatu organisasi pendidikan yang membedakannya dengan belajar sendiri; (3) Digunakannya media teknis; (4) Penyediaan interaksi komunikasi dua arah; (5) Kemungkinan pertemuan tatap muka secara sangat terbatas, dan (6) Adanya partisipasi kegiatan industrialisasi pendidikan.

Berbeda dengan perguruan tinggi tatap muka, sebuah PTJJ memungkinkan memberikan layanan pendidikan secara tanpa batas (mampu menjangkau daerah yang sangat luas), memberikan layanan belajar yang lebih fleksible, serta mampu menerapkan biaya pendidikan yang lebih terjangkau oleh seluruh lapisan masyarakat.

\section{B. Kesiapan Mahasiswa dalam Pembelajaran Daring}

Pembelajaran dalam jaringan (online learning) merupakan bentuk pembelajaran jarak jauh yang memanfaatkan fasilitas teknologi informasi dan komunikasi yang dilakukan melalui media internet (Baruah, 2018). Suasana pembelajaran online learning akan menuntut pelajar memainkan peranan yang lebih aktif dalam pembelajarannya. Online learning mengandung pengertian yang sangat luas, sehingga banyak pakar yang menguraikan tentang definisi online learning dari berbagai sudut pandang.

Pemanfaatan teknologi informasi dan komunikasi juga harus diimbangi dengan kemampuan teknis dan kematangan psikologis dalam penggunaannya. Kemampuan itu dikenal dengan istilah 'literasi TIK' (ICT literacy). ICT literacy adalah kemampuan untuk menggunakan teknologi digital, alat komunikasi dan atau jaringan dalam mendefinisikan (define), mengakses (access), mengelola (manage), mengintegrasikan (integrate), mengevaluasi (evaluate), menciptakan (create) dan mengkomunikasikan (communicate) informasi secara baik dan legal untuk menghasilkan sebuah konsep baru dalam rangka membangun masyarakat berpengetahuan (Katz \& Macklin-Smith, 2013).

Prensky (2001) berpendapat bahwa pesatnya perkembangan teknologi digital selama beberapa dekade terakhir telah memiliki pengaruh besar pada siswa. Menurut Prensky, "diskontinuitas" telah berkembang dan sebagai konsekuensinya, masyarakat sekarang dapat dikategorikan secara luas menjadi dua kelompok, "penduduk asli digital" dan "imigran digital". Sebagai penduduk asli digital, siswa saat ini "semuanya adalah 'penutur asli' dari bahasa digital komputer, video game, dan Internet" (Prensky, 2001, p. 1). Karya Prensky, yang kemudian diperluas oleh penulis lain, telah mengarah pada gagasan bahwa generasi pasca 1980-an, mereka yang telah tumbuh dengan akses ke komputer dan Internet, "pada dasarnya memahami teknologi" (Margaryan et al., 2011, p. 429). Dalam konteks universitas, yang telah melihat munculnya online learning sebagai metode yang lebih disukai, mungkin tampak masuk akal bahwa siswa yang mengerti teknologi ini akan sangat cocok untuk lingkungan belajar seperti itu (Parkes et al., 2015).

Mengaplikasikan pembelajaran daring harus didukung oleh kesiapan penyedia layanan (institusi pendidikan) dan juga kesiapan pengguna (mahasiswa) untuk dapat mengakses konten ataupun aktivitas pembelajaran yang disediakan secara online. Universitas Terbuka, sebagai institusi pendidikan yang sudah lama menerapkan pembelajaran secara online, sudah menyediakan beragam 
fasilitas untuk terlaksananya pembelajaran daring yang berkualitas; moda utama pembelajaran Daring di UT diwadahi dalam program Tutorial Online atau yang lebih dikenal dengan singkatan Tuton. Tuton merupakan salah satu kegiatan layanan bantuan belajar dengan platform Learning Management System (LMS) atau Sistem Manajemen Pembelajaran. LMS adalah aplikasi perangkat lunak untuk administrasi, dokumentasi, pelacakan, pelaporan dan penyampaian program pendidikan atau program pelatihan online learning. Aplikasi ini memungkinkan mahasiswa untuk masuk ke dalam "ruang kelas" virtual untuk mengakses materi-materi pembelajaran dan kegiatan interaksi akademik lainnya bersama tutor dan mahasiswa lainnya. Dengan menggunakan LMS, semua pihak yang terlibat terutama mahasiswa dan tutor dapat membuat materi pembelajaran, kuis, jurnal elektronik, dan lainnya. Berdasarkan pengalaman dan sejarah pengembangan UT, pemanfaatan teknologi internet sudah dirintis sejak tahun 1995 yang ditandai dengan lahirnya 'web UT'. Namun demikian implementasi internet berbasis LMS baru dimulai pada tahun 2000 mulai dari Blackboard, implementasi Manhattan Virtual Classroom pada tahun 2002, dan menggunakan Moodle versi 1.4 sebagai platform dasar UT Online pada tahun 2004. Pemanfaatan Moodle sebagai flatform utama layanan UT Online terus berkembang sampai dengan saat ini yang ditandai dengan melakukan upgrading pada setiap tahapan peluncuran versi/produk baru Moodle yang disesuaikan dengan dinamika dan kebutuhan layanan.

Sejumlah studi tentang pemanfaatan teknologi untuk pembelajaran daring telah banyak dilakukan. Ali dan Magalhaes (2008) telah mempelajari hambatan yang dihadapi dalam mengintegrasikan teknologi terutama online learning, mengidentifikasi dukungan manajemen, literasi teknologi, hambatan bahasa, beban pekerjaan, dan masalah manajemen waktu untuk belajar. Al-alak dan Alnawas (2011) telah meneliti dan mengidentifikasi manfaat mengikuti pembelajaran daring, persepsi terkait kemudahan penggunaan aplikasi, pengetahuan dan keterampilan terkait komputer, dukungan internal manajemen, serta hambatan utama dalam mengadopsi teknologi, melalui studi yang dilakukan terhadap dosen di Yordania. Khusus di negara-negara berkembang, terlepas dari faktor-faktor yang disebutkan di atas, aspek sosial ekonomi, aspek psikologis, kualitas teknologi dan konten merupakan isu utama yang paling banyak disampaikan (Butler \& Sellbom, 2002). Disamping itu, Mohammadi (2015) menemukan bahwa aspek sistem pendukung, manfaat yang dirasakan, serta kemudahan penggunaan merupakan faktor utama yang negatif yang berdampak pada adopsi teknologi dalam pedagogi.

\section{Kepuasan Mahasiswa terhadap Pembelajaran Daring}

Menurut Kotler dan Keller (2015) secara umum makna kepuasan pengguna jasa adalah terkait dengan perasaan senang atau kecewa (kurang/tidak senang) seseorang sebagai hasil dari perbandingan antara persepsi serta pengalaman atas jasa layanan yang dirasakan dengan yang diharapkan. Jika kinerja layanan yang dirasakan berada di bawah harapan, maka kecenderungannya pengguna jasa akan merasa tidak puas. Sebaliknya, jika unjuk kerja layanan yang dialami memenuhi harapan, maka kecenderungannya pengguna jasa layanan akan merasa puas. Atas dasar asumsi tersebut, kepuasan mahasiswa peserta pembelajaran daring akan terjadi jika institusi penyedia jasa layanan mampu menyediakan produk, proses pelayanan, harga dan aspek lain yang sesuai dengan harapan atau bahkan melebihi harapan mahasiswanya. Maka kepuasan mahasiswa peserta daring akan dirasakan dari layanan bantuan belajar tersebut yang sesuai dengan harapannya. 


\section{METODE}

Penelitian ini menggunakan metode penelitian kuantitatif-eksploratif yang didukung dengan kegiatan survei untuk mengetahui sejauh mana tingkat kesiapan dan kepuasan mahasiswa terhadap layanan proses pembelajaran di UT. Data dianalis untuk mengetahui konstribusi aspek manfaat, kendala, pendukung, dan prospek pembelajaran daring, menggunakan Multiple Correspondence Analysis (MCA) sebagai alat analisis yang memungkinkan teridentifikasinya karakterisasi peserta pembelajaran daring pada berbagai kategori aspek-aspek tersebut.

\section{A. Analisis Korespondensi Berganda (MCA)}

Analisis korespondensi berganda (Multiple Correspondence Analysis - MCA) adalah teknik multivariat dalam statistika untuk analisis tabel-tabel yang terdiri dari sejumlah kelompok variabel kategori dari pengamatan individu-individu yang sama (Husson, Lê \& Pagès, 2017). MCA merupakan aplikasi spesifik dari analisis korespondensi (Correspondence Analysis - CA) terhadap tabel-tabel yang berisi data pengamatan individu-individu dan jawaban mereka pada sejumlah variabel kategori. Meskipun demikian, metode ini dianggap sebagai metode terpisah karena sifatnya yang unik dan hasil menarik yang diperoleh saat menggunakannya. MCA diterapkan kepada tabel-tabel dengan pengamatan individu-individu pada baris dan variabel-variabel kategori pada kolom. Ini paling umum digunakan untuk menganalisis data yang diperoleh melalui survei; setiap pertanyaan dalam survey berkaitan dengan masing-masing suatu variabel dan setiap kemungkinan jawaban untuk pertanyaan tersebut berkaitan dengan sebuah kategori dari variabel itu. Untuk setiap variabel, individu harus memilih hanya satu kategori.

Dengan teknik analisis ini, dimungkinkan untuk mengkarakterisasi kelompok individu-individu, meringkas hubungan antar variabel ke dalam beberapa variabel sintesis (dimensi), dan mempelajari karateristik respon kategori-kategori variabel. Dalam MCA, analisis lebih difokuskan terutama terhadap studi kategori, karena kategori mewakili variabel dan sekelompok individu (semua individu yang memilih kategori ini). Interpretasi yang paling penting dari hasil analisis MCA dapat dilihat dari tiga hal sebagai berikut : (i) persentase inersia dimensi-dimensi, (ii) tingkat kontribusi dan representasi dari individu atau kategori terhadap dimensi-dimensi, dan, (iii) penjelasan dimensidimensi utama oleh semua variabel aktif maupun variabel tambahan (deskriptif). Selain itu, sebagai hasil visual analisis MCA, juga dapat dikonstruksi sebuah plot yang merepresentasikan posisi setiap kategori-variabel dalam sebuah bidang datar dua dimensi pertama yang memiliki persentase inersia terbesar. Prosedur dan hasil-hasil MCA ini dilakukan dengan menggunakan software $\mathrm{R}$ paket FactoMineR (Husson, Josse, Lê \& Mazet, 2017; Lê, Josse \& Husson, 2008).

\section{B. Variabel dan Instrumen Penelitian}

Variabel-variabel yang diteliti terdiri dari atas dua kelompok yaitu: (i) variabel-variabel deskriptif responden, dan (ii) variabel-variabel persepsi; masing-masing kelompok variabel tersebut berfungsi mengukur kesiapan dan kepuasan pembelajaran daring. Kelompok pertama meliputi variabel-variabel: status, lokasi, akses, literasi, keterampilan, dan motivasi responden. Kelompok kedua, meliputi variabel-variabel persepsi pada empat aspek (manfaat, kendala, faktor pendukung, dan prospek) pembelajaran daring. Daftar pertanayaan kedua kelompok variabel disajikan pada lampiran (Tabel L.1 dan Tabel L.2). Instrumen penelitian ini (kuesioner) dikembangkan oleh tim peneliti. Pertanyaan-pertanyaan yang dikemukakan dalam kuisioer mencakup kesiapan dan 
kepuasan responden dalam pembelajaran daring menurut variabel-variabel pada kelompok deskriptif maupun kelompok persepsi.

Populasi dalam penelitian ini adalah semua dosen, tutor, mahasiswa UT, dan mahasiswa non UT yang mengikuti proses pembelajaran daring UT tahun 2019 dan 2020. Sampel diambil dari partisipan pembelajaran yang meliputi wilayah Indonesia Barat, Tengah dan Timur, atau meliputi pulau : Sumatera, Jawa, Bali, Nusa Tenggara, Kalimantan, Sulawesi, Maluku, dan Papua.

\section{PEMBAHASAN}

\section{A. Kajian dan Partisipan Survey}

Survey ini dilaksanakan untuk memperoleh kesan keseluruhan pembelajaran daring dari pandangan para partisipan program pembelajaran daring di Universitas Terbuka, yaitu tutor dan mahasiswa, yang berasal dari UT atau pun non UT. Partisipan diminta menjawab 22 butir pertanyaan dalam dua set pertanyaan sebagaimana dijelaskan di atas.

Data lampiran pada Tabel L.3 menunjukkan bahwa jumlah partisipan 13.307 orang, 91,9\% adalah mahasiswa UT, 6,6\% mahasiswa non UT, dan 1,5\% adalah dosen/tutor UT atau non UT. Jumlah partisipan dosen/tutor 195 orang, 59,5\% dosen UT dan 40,5\% tutor non UT. Partisipan dosen/tutor maupun mahasiswa sebagian besar dari wilayah Sumatera $25,6 \%$ dan Jawa 49,7\%, selainnya dari wilayah lainnya.

\section{B. Akses dan Literasi Pembelajaran Daring Partisipan}

Pada aspek akses/literasi (P01-P04, data Tabel L.4 pada lampiran), akses partisipan kepada informasi cukup bervariasi, 81,8\% partisipan mempunyai akses informasi yang memadai, dan selainnya $(18,2 \%)$ tidak memiliki akses yang memadai (tidak memiliki komputer atau jaringan yang memadai). Literasi informasi partisipan umumnya hampir seragam, 93,3\% menyatakan teknologi informasi membuat proses pembelajaran menjadi lebih efektif. Keadaan jumlah partisipan menurut keadaan akses dan literasi ditunjukkan pada tabulasi silang pada Tabel 1. Nampak bahwa tingkat literasi daring partisipan dikarakterisasi oleh tingkat akses $(r=0,247, p .000)$.

Tabel 1. Distribusi Akses dan Literasi Pembelajaran Daring Partisipan

\begin{tabular}{lrrrrrrr}
\hline \multirow{2}{*}{ Akses } & \multicolumn{2}{c}{ Literasi, $n$} & \multirow{2}{*}{ Total } & & \multicolumn{2}{c}{ Literasi, \% } & \multirow{2}{*}{ Total } \\
\cline { 2 - 3 } \cline { 6 - 7 } & Tidak & Ya & & & Tidak & Ya & \\
\hline Tidak & 477 & 1.942 & 2.419 & & 3,58 & 14,59 & 18,18 \\
Ya & 408 & 10.480 & 10.888 & & 3,07 & 78,76 & 81,82 \\
\hline Total & 885 & 12.422 & 13.307 & & 6,65 & 93,35 & 100,0 \\
\hline
\end{tabular}

Note: Chi-square $=813,3 ; d f=1 ;$.value $=0,000 ;$ Spearman's rho 0,247.

Keterangan:

- $\quad$ Tingkat akses daring partisipan 81,8\%. Tingkat literasi daring partisipan 93,3\%.

- Tingkat akses dan literasi daring 78,76\%, tingkat literasi daring partisipan dikarakterisasi oleh tingkat akses. Tingkat akses berasosiasi dengan literasi atau sebaliknya $(r=0,247, p .000)$. Tingkat literasi daring bergantung tingkat akses. Terdapat 14,59\% partisipan literasi daring dari mereka yang tidak memiliki akses yang memadai. 


\section{Keterampilan Pembelajaran Daring Partisipan}

Pada aspek keterampilan (P03-P04, Tabel L.4), keterampilan teknologi informasi partisipan bervariasi atas tiga kelompok : sangat mahir $\pm 30 \%$, mahir $( \pm 40 \%)$, dan sedang/kurang/tidak mahir $( \pm 30 \%)$ dalam mencari sumber informasi atau menggunakan aplikasi komputer. Hubungan keterampilan penggunaan komputer dengan pencarian sumber informasi ditunjukkan pada Tabel 2. Nampak bahwa keterampilan daring partisipan dalam pencarian sumber informasi dikarakterisasi oleh kemampuan mereka dalam menggunakan berbagai aplikasi komputer $(r=0,749, p .000)$.

Tabel 2. Distribusi Keterampilan Pembelajaran Daring Partisipan

\begin{tabular}{|c|c|c|c|c|c|c|c|c|}
\hline \multirow{2}{*}{$\begin{array}{l}\text { Penggunaan } \\
\text { komputer }\end{array}$} & \multicolumn{4}{|c|}{ Pencarian Sumber informasi } & \multicolumn{4}{|c|}{ Pencarian Sumber informasi, \% } \\
\hline & S5 & S4 & S3 & All & S5 & S4 & S3 & All \\
\hline S5 & 2.596 & 356 & 59 & 3.011 & 19,5 & 2,7 & 0,4 & 22,6 \\
\hline S4 & 847 & 4.055 & 466 & 5.368 & 6,4 & 30,5 & 3,5 & 40,3 \\
\hline S3 & 196 & 1.288 & 3.444 & 4.928 & 1,5 & 9,7 & 25,9 & 37,0 \\
\hline All & 3.639 & 5.699 & 3.969 & 13.307 & 27,4 & 42,8 & 29,8 & 100,0 \\
\hline
\end{tabular}

Note: Chi-square $=11640,7 ; d f=4 ;$ p.value $=0,000 ;$ Spearman's rho 0,749;

S5, Mahir sekali; S4, Mahir; S3, Sedang/kurang/tidak mahir.

Keterangan:

- Tingkat keterampilan menggunakan aplikasi/komputer : $22,6 \%$ mahir sekali, $40,3 \%$ mahir, $37 \%$ sedang/kurang/tidak mahir. Tingkat keterampilan mencari sumber infomasi dengan internet: 27,4\% mahir sekali, $42,8 \%$ mahir, $29,8 \%$ sedang/kurang/tidak mahir.

- Keterampilan daring partisipan dalam pencarian sumber informasi dikarakterisasi oleh kemampuan mereka dalam menggunakan berbagai aplikasi komputer $(r=0,749, p .000)$.

\section{Pengalaman Motivasi Pembelajaran Daring Partisipan}

Pada aspek pengalaman motivasi dalam pembelajaran daring (P05-P06, Tabel L.4), motivasi partisipan bervariasi, dimana sekitar $70 \%$ mahasiswa/tutor menyatakan mereka lebih sering berinteraksi atau menilai tutor/mahasiswa memberikan umpan balik dalam pembelajaran daring, dan $30 \%$ selainnya. Menurut Tabel 3 , secara keseluruhan tingkat interaksi belajar daring partisipan $72,4 \%$ berasosiasi dengan tingkat umpan balik 70,4\% $(r=0,252, p .000)$.

Tabel 3. Distribusi Pengalaman Motivasi Pembelajaran Daring Partisipan

\begin{tabular}{|c|c|c|c|c|c|c|c|c|c|}
\hline \multirow[b]{3}{*}{ Interaksi } & \multirow{2}{*}{\multicolumn{3}{|c|}{$\begin{array}{l}\text { Dosen : } \\
\quad \text { Umpan balik }\end{array}$}} & \multirow{2}{*}{\multicolumn{3}{|c|}{$\begin{array}{l}\text { Mahasis wa : } \\
\text { Umpan balik }\end{array}$}} & \multirow{2}{*}{\multicolumn{3}{|c|}{ Umpan balik }} \\
\hline & & & & & & & & & \\
\hline & $\mathrm{Ya}$ & Tidak & Total & $\mathrm{Ya}$ & Tidak & Total & $\mathrm{Ya}$ & Tidak & Total \\
\hline$\overline{Y a}$ & 48,7 & 14,4 & 63,1 & 56,3 & 16,3 & 72,6 & 56,1 & 16,3 & 72,4 \\
\hline Tidak & 23,1 & 13,8 & 36,9 & 14,2 & 13,3 & 27,4 & 14,3 & 13,3 & 27,6 \\
\hline Total & 71,8 & 28,2 & 100,0 & 70,4 & 29,6 & 100,0 & 70,4 & 29,6 & 100,0 \\
\hline
\end{tabular}

Note: Chi-square (untuk All) = 846,191; $d f=1 ;$ p.value $=0,000 ;$ Spearman's rho $=0,252$.

Keterangan:

- Tingkat interaksi daring dosen/tutor $63,1 \%$, tingkat umpan balik dari mahasiswa $71,8 \%$. Tingkat interaksi daring mahasiswa $72,6 \%$, tingkat umpan balik dari dosen $70,4 \%$.

- Mahasiswa melakukan interaksi daring lebih banyak (sekitar $10 \%$ ) dari pada dosen/tutor, menerima umpan balik lebih sedikit dari dosen/tutor; atau, dosen melakukan interaksi daring lebih sedikit dari mahasiswa, menerima umpan balik lebih banyak dari mahasiswa.

- Secara keseluruhan tingkat interaksi belajar daring partisipan $72,4 \%$ berasosiasi dengan tingkat umpan balik $70,4 \%(r=0,252, p .000)$. 
Dengan demikian, deskripsi partisipan berbeda-beda dalam kondisi akses, keterampilan, dan pengalaman motivasi pembelajaran daring. Sementara itu, tingkat literasi pembelajaran daring partisipan relatif sama yang dikarakterisasi oleh tingkat akses yang dimilikinya. Keterampilan partisipan dalam mencari sumber informasi di internet dikarakterisasi oleh kemampuannya menggunakan komputer dan aplikasi-aplikasinya. Ini menunjukkan tingkat kesiapan internal partisipan. Sementara itu, tingkat interaksi daring partisipan berasosiasi dengan tingkat umpan baliknya. Ini berkaitan dengan kepuasan yang dialami partisipan dalam pembelajaran daringnya.

Gambaran ini sangat diwakili oleh mahasiswa (UT atau Non UT) karena sampelnya paling banyak dalam survey ini. Sebagai contoh, pada Tabel 4 disajikan kondisi literasi untuk status partisipan mahasiswa. Pada tabel tersebut, dari 93,3\% partisipan yang memiliki preferensi literasi pembelajaran daring, sebanyak $91,95 \%$ di dalamnya adalah literasi dari partisipan mahasiswa, artinya hanya $1,35 \%$ adalah literasi dari partisipan dosen/tutor. Juga, dari 6,7\% partisipan yang tidak memiliki preferensi literasi pada pembelaran daring, 6,6\% di dalamnya adalah partisipan mahasiswa (UT 5,0\% dan non UT 1,6\%). Demikian juga, 18,2\% partisipan yang tidak memiliki akses yang memadai, $18,1 \%$ di dalamnya adalah mahasiswa (UT 15,2\% dan non UT 2,9\%).

Tabel 4. Literasi Pembelajaran Daring Partisipan Mahasiswa

\begin{tabular}{|c|c|c|c|c|c|c|c|c|}
\hline & \multicolumn{2}{|c|}{ Akses } & \multicolumn{2}{|c|}{ Literasi } & \multicolumn{2}{|c|}{ Akses, $\%$} & \multicolumn{2}{|c|}{ Literasi, \% } \\
\hline & $\mathrm{Ya}$ & Tidak & $\mathrm{Ya}$ & Tidak & $\mathrm{Ya}$ & Tidak & $\mathrm{Ya}$ & Tidak \\
\hline Mhs Non UT & 498 & 386 & 670 & 214 & 3,7 & 2,9 & 5,03 & 1,6 \\
\hline Mhs UT & 10204 & 2024 & 11566 & 662 & 76,7 & 15,2 & 86,92 & 5,0 \\
\hline Mahasiswa & 10702 & 2410 & 12236 & 876 & 80,4 & 18,1 & 91,95 & 6,6 \\
\hline
\end{tabular}

\section{F. Persepsi dan Opini Partisipan}

Distribusi persepsi dan opini pembelajaran daring partisipan disajikan pada Tabel 5. Pada aspek manfaat, persepsi partisipan umumnya terbagi atas tiga kelompok kategori: sangat setuju, setuju, atau kurang/tidak setuju kepada pemanfaatan pembelajaran daring, dari segi fleksibilitas (M1) atau proses (M2). Persepsi yang lebih bervariasi ditunjukkan partisipan atas biaya pembelajaran daring (M3), terbagi atas empat kategori respon.

Pada aspek kendala, persepsi mahasiswa terhadap kemampuan akses internet tutor sangat bervariasi (K1), dan/atau sebaliknya, persepsi tutor terhadap kemampuan akses internet mahasiswa sangat bervariasi (ditunjukkan oleh prosentase yang cukup tinggi terdistribusi pada lima kategori respon). Persepsi partisipan sangat bervariasi juga ditunjukkan pada: persiapan infrastruktur TIK pembelajaran daring (K2), kemampuan mahasiswa (dosen) menggunakan teknologi (K3), dan kelambatan respon/umpan balik mahasiswa (tutor) dalam pembelajaran daring (K4). Pada aspek faktor pendukung (F1-F4), persepsi partisipan umumnya terbagi atas tiga kelompok kategori: sangat setuju, setuju, atau kurang/tidak setuju kepada faktor pendukung pembelajaran daring, dari segi kebijakan pemerintah, kecenderungan generasi muda, infrastruktur TIK, atau harga perangkat teknologi/komputer.

Pada aspek prospek pembelajaran daring (P1-P2), juga, persepsi partisipan umumnya terbagi atas tiga kelompok kategori: sangat setuju, setuju, atau kurang/tidak setuju atas sumber pembelajaran atau pun semangat sosialisasi partisipasi kepada sejawatnya. Ragam pendapat partisipan mengenai pembelajaran daring saat terjadi pandemic COVID 19 terbagi atas empat 
kelompok kategori, yaitu : sangat setuju 64,8\%, setuju (dengan catatan-catatan tertentu) 16,9\%, netral/tidak berpendapat 10,1\%, dan kurang/tidak setuju 8,2\%.

Kelompok-kelompok partisipan yang terbentuk dari respon pada masing-masing aspek menunjukkan variasi persepsi kesiapan dan kepuasan yang dialami partisipan pembelajaran daring. Pada Tabel L.2, kesiapan hipotetik partisipan didominasi oleh aspek kendala dan faktor pendukung; sementara kepuasan didominasi oleh aspek manfaat dan prospek.

\section{Tabel 5. Distribusi Persepsi dan Opini Pembelajaran Daring Partisipan}

\begin{tabular}{|c|c|c|c|c|c|c|c|c|c|c|c|c|}
\hline \multirow[b]{2}{*}{ No. } & \multirow[b]{2}{*}{ Kode } & \multirow[b]{2}{*}{ Pertanyaan } & \multicolumn{5}{|c|}{ Frekuensi } & \multicolumn{5}{|c|}{$\%$} \\
\hline & & & S5 & S4 & S3 & S2 & $\overline{\text { S1 }}$ & S5 & S4 & S3 & S2 & S1 \\
\hline 1 & M1 & Pembelajaran daring bisa dilakukan kapan saja dan dimana saja & 7.436 & 3.693 & 1.698 & 292 & 188 & 55,9 & 27,8 & 12,8 & 2,2 & 1,4 \\
\hline 2 & M2 & $\begin{array}{l}\text { Pembelajaran daring membuat proses pembelajaran lebih } \\
\text { terorganisasi }\end{array}$ & 3.668 & 4.660 & 3.845 & 808 & 326 & 27,6 & 35,0 & 28,9 & 6,1 & 2,4 \\
\hline 3 & M3 & Biaya untuk pembelajaran daring lebih murah & 5.014 & 3.493 & 3.017 & 1.053 & 730 & 37,7 & 26,2 & 22,7 & 7,9 & 5,5 \\
\hline 4 & K1 & Tidak semua mahasiswa (dosen) memiliki akses internet & 2.700 & 2.922 & 4.115 & 1.706 & 1.864 & 20,3 & 22,0 & 30,9 & 12,8 & 14,0 \\
\hline 5 & $\mathrm{~K} 2$ & $\begin{array}{l}\text { Persiapan infrastruktur TIK untuk pembelajaran daring memerlukan } \\
\text { pembiayaan yang besar }\end{array}$ & 2.409 & 3.355 & 4.605 & 1.752 & 1.186 & 18,1 & 25,2 & 34,6 & 13,2 & 8,9 \\
\hline 6 & K3 & Mahasiswa (dosen) tidak mampu menggunakan teknologi & 394 & 1.173 & 3.871 & 3.335 & 4.534 & 3,0 & 8,8 & 29,1 & 25,1 & 34,1 \\
\hline 7 & K4 & $\begin{array}{l}\text { Respon yang tertunda dari mahasiswa (tutor) membuat frustasi } \\
\text { tutor (mahasiswa) }\end{array}$ & 2.296 & 2.994 & 5.004 & 1.641 & 1.372 & 17,3 & 22,5 & 37,6 & 12,3 & 10,3 \\
\hline 8 & $\mathrm{~F} 1$ & $\begin{array}{l}\text { Kebijakan pemerintah sebagai faktor pendukung untuk } \\
\text { menggunakan pembelajaran daring }\end{array}$ & 4.342 & 4.720 & 3.552 & 430 & 263 & 32,6 & 35,5 & 26,7 & 3,2 & 2,0 \\
\hline 9 & $\mathrm{~F} 2$ & Generasi muda sekarang lebih menyukai pembelajaran jarak jauh & 3.548 & 4.192 & 4.149 & 911 & 507 & 26,7 & 31,5 & 31,2 & 6,8 & 3,8 \\
\hline 10 & F3 & $\begin{array}{l}\text { Infrastruktur teknologi, informasi dan komunikasi mendukung } \\
\text { pembelajaran jarak jauh }\end{array}$ & 5.381 & 4.524 & 2.712 & 453 & 237 & 40,4 & 34,0 & 20,4 & 3,4 & 1,8 \\
\hline 11 & F4 & $\begin{array}{l}\text { Harga komputer yang semakin murah mendukung penggunaan } \\
\text { pembelajaran daring }\end{array}$ & 3.308 & 3.512 & 4.136 & 1.386 & 965 & 24,9 & 26,4 & 31,1 & 10,4 & 7,3 \\
\hline 12 & P1 & $\begin{array}{l}\text { Sumber pembelajaran terbuka di Internet memberikan prospek yang } \\
\text { cerah untuk pembelajaran daring }\end{array}$ & 4.328 & 5.090 & 3.286 & 422 & 181 & 32,5 & 38,3 & 24,7 & 3,2 & 1,4 \\
\hline 13 & $\mathrm{P} 2$ & $\begin{array}{l}\text { Saya akan merekomendasikan pembelajaran daring ke sesama } \\
\text { mahasiswa (tutor) yang lain }\end{array}$ & 3.947 & 4.586 & 3.848 & 657 & 269 & 29,7 & 34,5 & 28,9 & 4,9 & 2,0 \\
\hline 14 & PC & $\begin{array}{l}\text { Bagaimana pendapat Anda mengenai pembelajaran daring saat } \\
\text { terjadi pandemic COVID } 19\end{array}$ & 8.625 & 2.246 & 1.343 & 964 & 129 & 64,8 & 16,9 & 10,1 & 7,2 & 1,0 \\
\hline
\end{tabular}

Catatan: S5, Sangat setuju; S4, Setuju; S3, Kurang setuju; S2, Tidak setuju; S1, Sangat tidak setuju.

\section{G. Asosiasi variabel-variabel persepsi pembelajaran daring}

Analisis asosiasi ini untuk memunculkan karakterisasi partisipan yang berhubungan dengan persepsi atau opini pembelajaran daring. Dalam hal ini, mengasosiasikan antar masing-masing 14 variabel persepsi dan opini program pembelajaran daring, sehingga dapat dimunculkan struktur utama asosiasi dalam bentuk dimensi-dimensi utama komponen principal yang memiliki keragaman data terbesar. Termasuk dalam analisis ini adalah memeriksa asosiasi kategori jawaban pertanyaan "Bagaimana pendapat Anda mengenai pembelajaran daring saat terjadi pandemic COVID 19?" dengan kategori-kategori variabel lainnya karena besar kemungkinan partisipan yang menjawab setuju atau sangat setuju memiliki kedekatan preferensi pembelajaran daring dengan individu lainnya.

Prosedur statistik ini adalah melakukan estimasi parameter asosiasi, dimensi-dimensi utama, dan variabilitas dari masing-masing dimensi. Analisis asosiasi antar variabel-variabel dilakukan dengan cara memproyeksikan posisi masing-masing kategori-variabel ke dalam plot bidang datar dua dimensi utama yang paling besar mewakili variasi data (umumnya dimensi kesatu dan kedua).

Sebagai hasilnya, asosiasi antar kategori 14 variabel ini diproyeksikan pada dua dimensi pertama yang memiliki keragaman data terbesar (Dim 1 dan Dim 2), disajikan pada Gambar 1. Total 
persentase variabilitas yang diwakili oleh Dim 1 dan Dim 2 ini adalah 25,0\% dengan persentase variabilitas Dim 1 adalah 15,06\%. Persentase ini, meskipun relatif kecil namun lebih besar dari persentase variabilitas minimal yang disyaratkan untuk mewakili struktur utama dari 14 variabel yaitu 24,5\% untuk total kedua dimensi dan 13,2\% untuk dimensi pertamanya (Husson, Lê \& Pagès, 2017, p. 225-227). Jadi, Dim 1 dan Dim 2 pada gambar tersebut dapat dianggap sebagai struktur utama dari 14 variabel persepsi/opini pembelajaran daring.

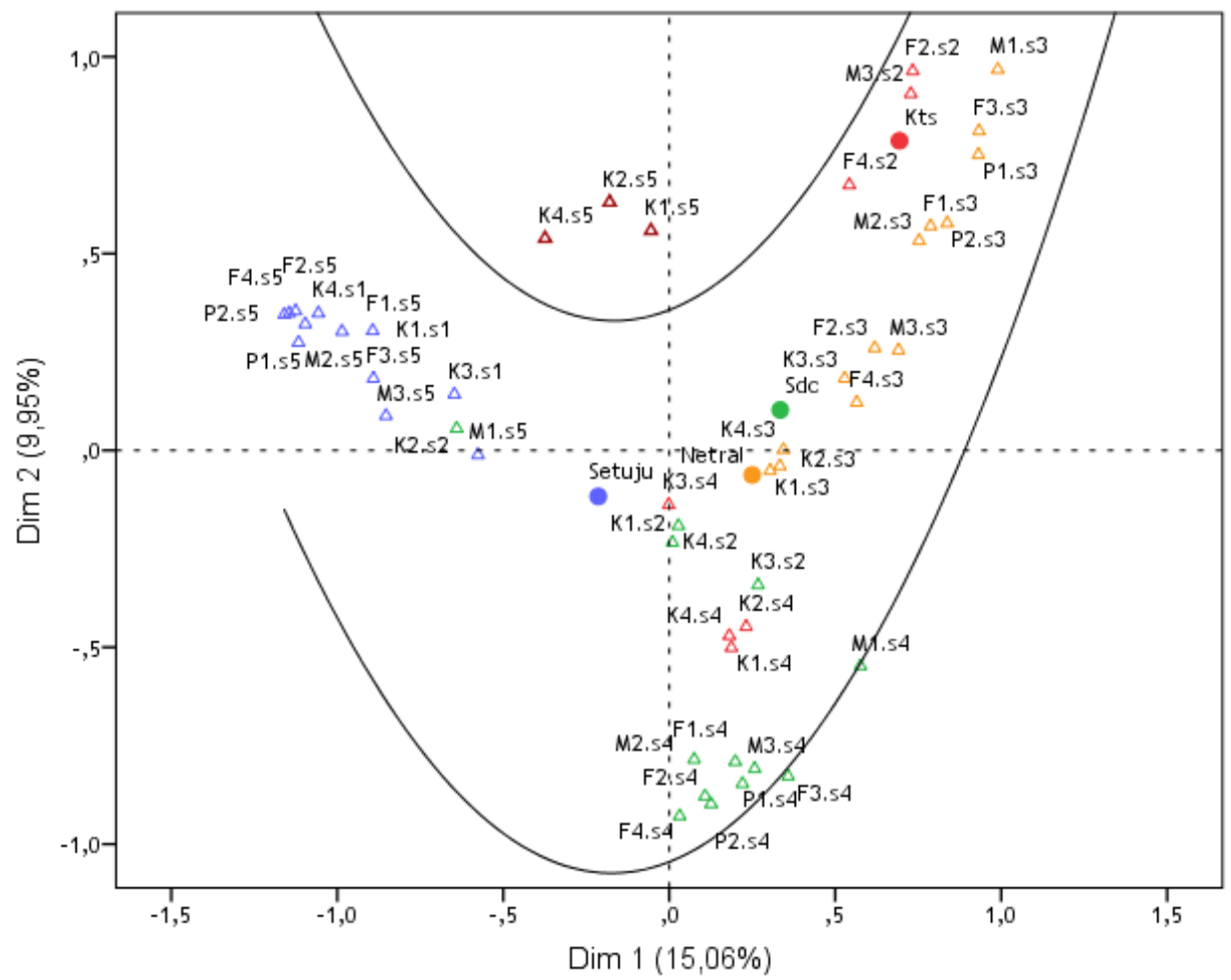

Catatan: (i) Kelompok variabel: M., Manfaat; K., Kendala; F., Faktor pendukung; P., Prospek; (ii) Kategori persepsi: s5, Sangat setuju; s4, Setuju; s3, Kurang setuju; s2, Tidak setuju; s1, Sangat tidak setuju; (iii) Kategori opini partisipan: Setuju, Sangat Setuju; Sdc, Setuju; Netral, Netral/tidak berpendapat; Kts, Kurang/tidak setuju.

Gambar 1. Representasi kategori-kategori persepsi partisipan dalam pembelajaran daring

Pada Gambar 1, posisi dua titik yang berdekatan menunjukkan asosiasi yang kuat antara dua kategori respon variabel. Tebaran titik kategori respon tersebut berbentuk seperti suatu parabola, ini dikenal sebagai efek Guttman (atau efek tapal kuda). Efek ini menggambarkan redundansi variabel-variabel ke dalam dimensi pertama, atau dengan kata lain, setiap kategori respon partisipan sangat terstruktur menurut dimensi pertama. Efek ini mempunyai gradien linier, dalam hal ini, perubahan posisi kategori pada dimensi pertama semakin lebar seiring dengan naiknya posisi pada dimensi kedua, dan sebaliknya perbedaan semakin kecil jika dimensi kedua turun. Ini ditandai dengan, pertama, posisi ekstrem berlawanan beberapa kategori variabel di sebelah kanan (warna 
merah atau kuning) lawan kategori-variabel di sebelah kiri (warna biru), dan, kedua, posisi yang lebih moderat ditunjukkan oleh sejumlah kategori variabel yang terletak di sepanjang dimensi kedua.

Jadi, menurut efek ini, individu partisipan atau pun kategori respon variabel terbagi atas tiga kelompok, dua kelompok ekstrim yang saling berlawanan (kiri vs kanan), dan satu kelompok moderat. Posisi di ekstrim kiri (marka kategori variabel warna biru) Gambar 1 adalah pandangan kelompok partisipan yang mempunyai persepsi tinggi terhadap pembelajaran daring, yaitu mereka sangat setuju pada aspek manfaat, faktor pendukung, dan prospek, atau sangat/tidak setuju pada aspek kendala pembelajaran daring. Sebaliknya, posisi ekstrim di sebelah kanan (marka kategori variabel warna merah atau kuning) adalah mewakili preferensi rendah partisipan terhadap pembelajaran daring, persepsi partisipan menyangsikan manfaat, faktor pendukung, atau pun prospek pembelajaran daring. Partisipan ini sangat tidak setuju bahwa biaya pembelajaran daring lebih murah (M3.s2), generasi muda yang lebih menyukai pembelajaran jarak jauh (F2.s2), dan harga komputer yang semakin murah (F4.s2). Juga, mereka kurang setuju dengan pernyataan bahwa kebijakan pemerintah dan kondisi infrastruktur TIK mendukung pembelajaran jarak jauh.

Posisi ketiga adalah posisi yang lebih moderat, tebaran posisi kategori-kategori variabelnya terletak di bagian tengah dan bawah pada Gambar 1. Partisipan pada kelompok ini memandang setuju pembelajaran daring, dari aspek-aspek manfaat, faktor pendukung, dan prospeknya (marka kategori warna hijau), akan tetapi sebagian dari mereka setuju atau sangat setuju masih adanya kendala pembelajaran daring (marka warna merah), yaitu tentang: Kemampuan akses internet, penggunaan teknologi, dan respon umpan balik dari mahasiswa/dosen, serta infrastruktur TIK pembelajaran daring memerlukan biaya besar.

Jadi posisi persepsi partisipan dalam pembelajaran daring adalah sangat menerima, menentang, dan moderat. Pada posisi menentang ini, opini partisipan terhadap program pembelajaran daring dalam situasi Covid-19 menyatakan kurang atau tidak setuju, posisi kategori ini adalah titik bulat merah pada Gambar 1 . Mereka yang juga menentang program ini tidak lagi melihat aspek kendala melainkan lebih karena masih sangat meragukan biaya dan kesiapan faktor pendukung pembelajaran daring. Pada kelompok partisipan moderat atau relatif lebih dekat dengan moderat, opini terhadap program pembelajaran daring dalam situasi Covid-19, berbeda-beda, yaitu setuju (titik bulat biru), setuju dengan catatan (titik bulat hijau), dan netral (titik bulat kuning). Mereka yang setuju program ini lebih berasosiasi dengan ciri-ciri kelompok ektrim menerima yaitu mereka dengan persepsi pembelajaran daring tinggi. Mereka yang setuju tetapi dengan catatan atau netral adalah mereka yang dekat dengan ciri-ciri partisipan moderat yang memperhatikan kendala yang masih ada.

Tradisi fenomenologi memberikan penekanan sangat kuat pada persepsi dan konsepsi (interpretasi) pada pengalaman subjektif manusia Griffin (2019). Persepsi adalah proses pemahaman sesuatu melalui pancaindera. Istilah resepsi dikemukakan oleh Stuart Hall dan David Morley dalam sebuah teori penerimaan pesan khalayak (Audience Reception Theory atau Reception Theory), adalah teori yang menekankan pada peran pembaca atau khalayak dalam menerima pesan, bukan pada peran pengirim pesan (Danesi, 2014). Pemaknaan pesan bergantung pada latar belakang budaya dan pengalaman hidup khalayak itu sendiri. Hal ini menunjukkan bahwa makna dalam sebuah teks tidak melekat pada teks, tetapi dibentuk pada hubungan antara teks dan pembaca. Marris dan Thornham (2005) menjelaskan bahwa terdapat tiga tipe penerimaan pesan, yaitu: (1) Dominan. Ketika khalayak menerima pesan dari media secara penuh dan memaknai pesan tersebut seperti yang diinginkan oleh media maka khalayak berada pada posisi yang dominan. Dalam hal ini berlangsung pertukaran komunikasi yang sempurna; (2) Negosiasi. Khalayak cukup memahami apa 
yang ditampilkan oleh media, tetapi tidak semua dimaknai sama. Penerimaan dalam tipe ini mengandung unsur adaptif dan oposisi. Hal ini menunjukkan bahwa pesan dinegosiasikan; dan, (3) Alternatif atau oposisi. Ketika khalayak sama sekali menolak pesan yang disampaikan media maka khalayak tersebut berada pada posisi oposisi. Mereka menolak pesan tersebut karena tidak sesuai dengan pengetahuan atau nilai yang dianutnya.

Apakah persepsi/opini program pembelajaran daring partisipan bersesuaian dengan deskripsi partisipan: Akses, literasi, keterampilan, dan pengalaman motivasi, serta status dan lokasinya. Dengan kata lain, tujuan analisis berikutnya adalah melihat apakah pola persepsi di atas memiliki asosiasi dengan deskripsi individu partisipan pembelajaran daring (status, lokasi, akses, literasi, keterampilan, dan pengalaman motivasi). Asosiasi ini dapat dilihat dalam proyeksi masingmasing kategori dari 8 variabel deskriptif pada bidang Dimensi 1 dan Dimensi 2, disajikan pada Gambar 2.

Kelompok posisi persepsi menerima (kiri) mempunyai ciri tingkat keterampilan partisipan dalam pembelajaran daring tinggi (mahir sekali). Pada posisi moderat, partisipan umumnya memiliki tingkat keterampilan, akses, literasi, dan motivasi pembelajaran daring, dan statusnya adalah dosen/tutor, atau mahasiswa UT. Pada kelompok posisi persepsi menentang (kanan), tampak ciri yang menonjol (marka titik warna merah/kuning), adalah partisipan yang tidak memiliki akses/literasi atau pun motivasi pembelajaran daring, dan keterampilan pembelajaran daring rendah. Sebagian persepsi mereka diwakili oleh mahasiswa non UT (yang dalam hal ini sebagian besar atau hampir seluruhnya berlokasi di wilayah UPBJJ UT Padang). Asosiasi lokasi partisipan di wilayah UPBJJ UT, sebagian besar berasosiasi dengan posisi moderat, dan sebagian kecil berasosiasi dengan posisi ektrim persepsi menerima (kiri). 


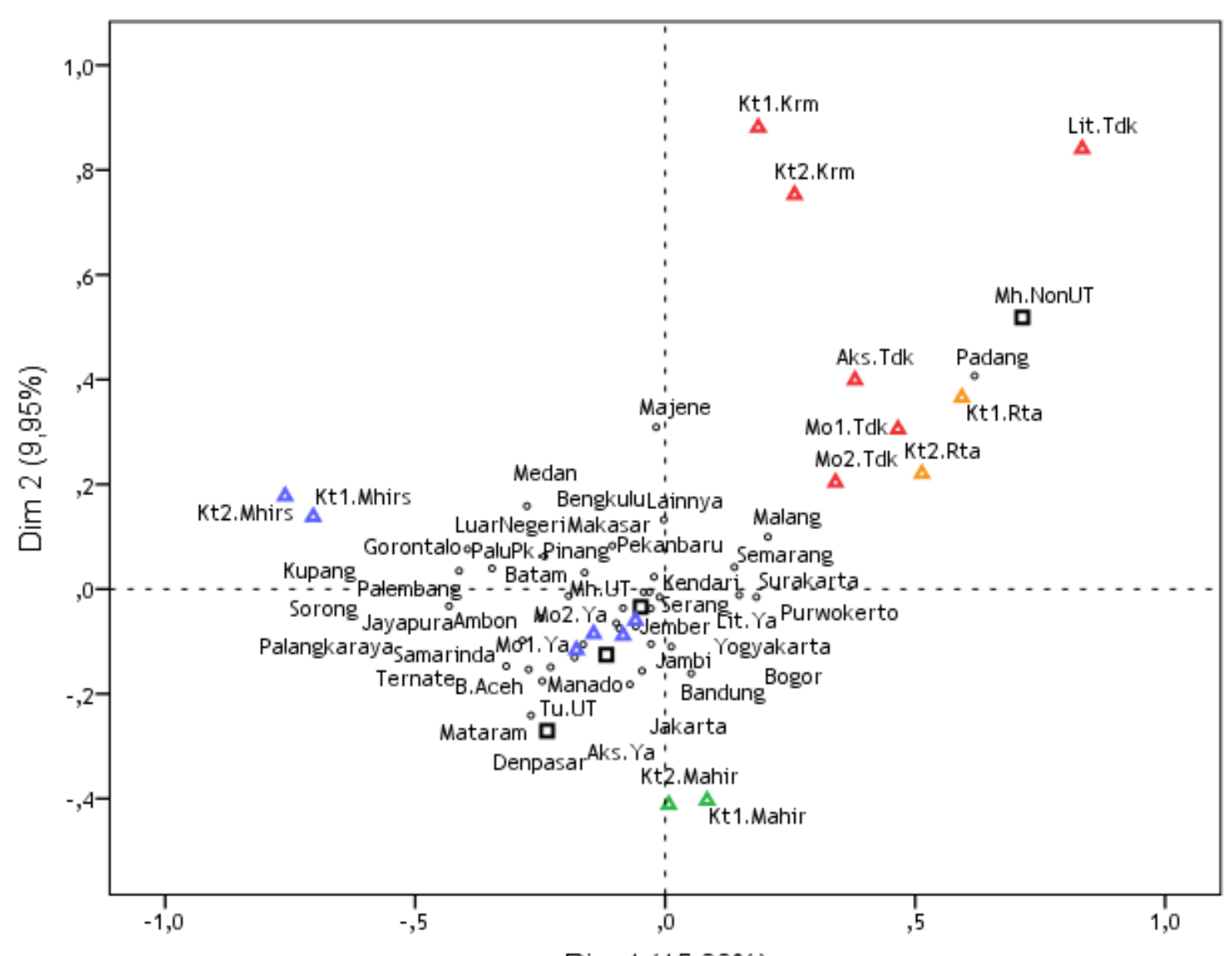

$\operatorname{Dim} 1(15,06 \%)$

Catatan: (i) Variabel: Aks, Akses; Lit, Literasi; Kt., Keterampilan; Mo., Motivasi; (ii) Kategori: Mh.UT, Mahasiswa UT; Mh.Non UT, Mahasiswa Non UT; Tu.UT, Tutor/dosen UT; Tu.Non UT, Tutor non UT; Tdk, Tidak; Krm, Kurang mahir; Rta, Sedang/cukup mahir; Mahirs, Mahir Sekali.

Gambar 2. Representasi kategori-kategori variabel deskriptif partisipan dalam pembelajaran daring

Pola pada Gambar 2 memunculkan struktur yang kuat hanya antar dua variabel dalam aspek yang sama, yaitu aspek keterampilan pembelajaran daring (antara pencarian sumber informasi di internet dan penggunaan komputer/aplikasi), dan aspek pengalaman motivasi (antara interaksi dan umpan balik dalam pembelajaran daring). Namun, "gagal" menunjukkan struktur tertentu antar kedua aspek tersebut, maupun hubungannya dengan variabel akses, dengan literasi pembelajaran daring, atau pun dengan status dan lokasi UPBJJ UT.

Kategori sangat mahir mencari sumber informasi di internet, berlawanan dengan kategori kurang/tidak mahir, dan kategori mahir pada ketiga posisi berbeda persepsi partisipan. Kategorikategori tingkat kemahiran dalam penggunaan komputer/aplikasi. Demikian juga, kategori tidak lebih sering berinteraksi dalam pembelajaran daring berbeda posisi persepsi partisipan dengan kategori ya. Kategori tidak bahwa mahasiswa (tutor) cepat memberikan respon/umpan balik berbeda posisi dengan kategori ya, yaitu pada posisi yang menentang pembelajaran daring dengan persepsi partisipan moderat. 
Hubungan masing-masing variabel deskriptif selainnya dengan persepsi terjadi pada dua posisi, yaitu moderat dan menentang. Kategori tidak variabel akses atau literasi pada posisi menentang, berlawanan dengan kategori ya masing-masing pada posisi moderat. Demikian juga dengan kategori status partisipan. Perbedaan posisi kategori status partisipan hanya terjadi pada mahasiswa non UT di satu sisi dengan satus lainnya pada posisi moderat. Sementara itu, perbedaan lokasi UPBJJ hanya terjadi antara Padang dengan UPBJJ lainnya pada posisi yang berbeda. Namun hal lebih dikarenakan pengaruh dari sampel status mahasis non UT yang dominan lokasinya adalah di wilayah UPBJJ UT Padang.

\section{Kontribusi Aspek/Variabel kepada Dimensi-dimensi}

Kontribusi setiap variabel persepsi kepada Dim 1 dan Dim 2, disajikan pada Tabel 10, mengukur sejauh mana variabel-variabel menentukan struktur utama atau posisi persepsi dan opini partisipan pembelajaran daring. Analisis di atas didesain bahwa hanya butir-butir pertanyaan pada kelompok (set) kedua yang aktif membentuk persepsi/opini pembelajaran daring partisipan, kelompok pertanyaan ini berkaitan langsung dengan opini pembelajaran daring partisipan. Struktur utama (Dim 1 dan Dim 2) persepsi partisipan dibentuk dari asosiasi antar kategori-kategori pada 14 variabel aktif ini, sehinggga masing-masing kategori variabel berkontribusi terhadap variabilitas Dim 1 dan Dim 2. Berbeda dengan variabel aktif, kelompok variabel deskriptif (pertanyaan pada set pertama) didesain sebagai variabel ilustratif untuk membandingkan atau menjelaskan struktur utama (posisi) persepsi partisipan menurut karakteristik individu pembelajaran daring partisipan, sehingga 8 variabel-variabel ini tidak menentukan langsung posisi persepsi pembelajaran daring partisipan, melainkan dilihat sejauh mana berasosiasi dengan posisi-posisi persepsi tersebut. Pada Tabel 6, variabel deskriptif hanya mempunyai tingkat asosiasi $\left(\mathrm{R}^{2}\right.$ atau Eta $\left.{ }^{2}\right)$ dengan dimensi-dimensi.

Total kontribusi masing-masing aspek relatif sama kepada dimensi pertama atau kedua, namun berbeda-beda dalam satu dimensi. Pada Dim 1 atau Dim 2, tiga aspek mempunyai total kontribusi yang besar, berturut-turut dari yang terbesar, adalah: faktor pendukung, manfaat atau prospek. Hal ini terjadi karena pertentangan posisi persepsi yang sangat berbeda pada level kategori-kategori setiap variabel dalam ketiga aspek tersebut. Secara umum, pada masing-masing dimensi, aspek pendukung berkontribusi sekitar $37 \%$, aspek prospek $25 \%$, aspek manfaat $23 \%$, dan aspek kendala $11 \%$, terhadap pembentukan persepsi pembelajaran daring partisipan. Dengan demikian, ini menunjukkkan bahwa partisipan sangat berbeda pandangan mengenai kesiapan dan kepuasan pembelajaran daring yang terlihat pada aspek-aspek pendukung, manfaat atau prospek pembelajaran daring dari pada aspek kendalanya.

Sementara itu, pada variabel deskriptif pembelajaran daring partisipan, terlihat bahwa dua variabel keterampilan pembelajaran daring mempunyai kualitas penjelasan atau konfirmasi yang efektif kepada posisi persepsi pembelajaran daring partisipan. Kedua variabel tersebut adalah kemampuan mencari sumber informasi di internet $\left(R^{2} .0,228\right.$ dan $\left.R^{2} .0,147\right)$, dan kemampuan menggunakan berbagai aplikasi komputer untuk menyelesaikan tugas $\left(R^{2} \cdot 0,212\right.$ dan $\left.R^{2} \cdot 0,136\right)$. 
Tabel 6. Kontribusi Variabel-variabel kepada Dimensi-dimensi

\begin{tabular}{|c|c|c|c|c|c|}
\hline \multirow[b]{2}{*}{ No. } & \multirow[b]{2}{*}{ Aspek/Variabel } & \multicolumn{2}{|c|}{$R^{2}$} & \multicolumn{2}{|c|}{ Kontribusi (\%) } \\
\hline & & $\operatorname{Dim} 1$ & $\overline{\operatorname{Dim} 2}$ & $\operatorname{Dim} 1$ & $\operatorname{Dim} 2$ \\
\hline & Manfaat: & & & $\underline{25,63}$ & $\underline{23,23}$ \\
\hline 1 & M1 & 0,438 & 0,237 & 7,65 & 6,25 \\
\hline 2 & M2 & 0,558 & 0,343 & 9,74 & 9,07 \\
\hline \multirow[t]{2}{*}{3} & M3 & 0,471 & 0,299 & 8,23 & 7,91 \\
\hline & Kendala: & & & $\underline{12,76}$ & $\underline{11,32}$ \\
\hline 4 & K1 & 0,149 & 0,139 & 2,60 & 3,68 \\
\hline 5 & K2 & 0,148 & 0,124 & 2,59 & 3,27 \\
\hline 6 & K3 & 0,242 & 0,048 & 4,23 & 1,28 \\
\hline \multirow[t]{2}{*}{7} & K4 & 0,191 & 0,117 & 3,34 & 3,09 \\
\hline & Faktor Pendukung: & & & $\underline{36,91}$ & $\underline{39,89}$ \\
\hline 8 & F1 & 0,529 & 0,355 & 9,24 & 9,39 \\
\hline 9 & $\mathrm{~F} 2$ & 0,530 & 0,396 & 9,26 & 10,46 \\
\hline 10 & F3 & 0,588 & 0,415 & 10,27 & 10,96 \\
\hline \multirow[t]{2}{*}{11} & $\mathrm{~F} 4$ & 0,466 & 0,344 & 8,15 & 9,08 \\
\hline & Prospek: & & & $\underline{\mathbf{2 4 , 7 0}}$ & $\underline{\mathbf{2 5 , 5 7}}$ \\
\hline 12 & P1 & 0,663 & 0,472 & 11,59 & 12,49 \\
\hline 13 & $\mathrm{P} 2$ & 0,656 & 0,433 & 11,46 & 11,44 \\
\hline \multirow[t]{2}{*}{14} & $\mathrm{PC}$ & 0,094 & 0,062 & 1,65 & 1,63 \\
\hline & Deskriptif variabel: & & & & \\
\hline 15 & $\mathrm{Kt} 1$ & 0,228 & 0,147 & & \\
\hline 16 & Kt2 & 0,212 & 0,136 & & \\
\hline 17 & Mo1 & 0,083 & 0,036 & & \\
\hline 18 & Lok & 0,054 & 0,028 & & \\
\hline 19 & Lit & 0,050 & 0,050 & & \\
\hline 20 & Mo2 & 0,049 & 0,017 & & \\
\hline 21 & Stat & 0,037 & 0,020 & & \\
\hline 22 & Aks & 0,032 & 0,035 & & \\
\hline
\end{tabular}

Catatan: $R^{2}$ untuk setiap variabel, p.value $=0,000$.

\section{KESIMPULAN}

Hubungan antara tiga kelompok tebaran kategori-kategori variabel menunjukkan tiga posisi yang sangat berbeda dalam hal persepsi/opini pembelajaran daring partisipan, yaitu posisi menerima, moderat, atau menentang. Opini program pembelajaran daring (dalam situasi Covid-19) partisipan berbeda pandangan pada posisi menentang di satu sisi dengan posisi moderat pada sisi yang lain, terutama berkaitan dengan biaya, trend, dan harga komputer/peralatan penunjang partisipan pembelajaran daring.

Ketiga posisi ini dibandingkan (konfirmasi) dengan kemampuan partisipan dalam mencari sumber informasi di internet dan menggunakan berbagai aplikasi dalam komputer untuk menyelesaikan tugas-tugas. Hubungan antar kedua variabel keterampilan ini sangat kuat saling berkaitan pada ketiga posisi tersebut. Pada dua posisi, persepsi moderat dan menentang, kedua posisi ini dibandingkan dengan intensitas interaksi dan umpan balik dalam pembelajaran daring. 
Hubungan antar kedua variabel pengalaman motivasi ini cukup kuat saling berkaitan pada kedua posisi ini. Selain itu, kedua posisi partisipan ini juga dibandingkan dengan masing-masing kondisi akses, literasi pembelajaran daring, atau status partisipan, yang masing-masing variabel ini berkaitan dengan kedua posisi tersebut.

Secara struktural, aspek pendukung berkontribusi sekitar $37 \%$, aspek prospek $25 \%$, aspek manfaat $23 \%$, dan aspek kendala $11 \%$, terhadap persepsi pembelajaran daring partisipan. Ini menunjukkan bahwa partisipan lebih berbeda pandangan pada aspek-aspek pendukung, manfaat atau prospek pembelajaran daring dari pada aspek kendalanya. Ini menunjukkan partisipan berbeda pandangan mengenai kesiapan dan kepuasan pembelajaran daring.

\section{REFERENSI}

Al-alak, B. A., \& Alnawas, I. A. (2011). Measuring the acceptance and adoption of e-learning by academic staff. Knowledge Management E-Learning International Journal, 3, 201-221.

Ali, G. E., \& Magalhaes, R. (2008). Barriers to implementing e-learning: A Kuwaiti case study. International Journal of Training and Development, 12(1), 36-53. https://doi.org/10.1111/j.1468-2419.2007.00294.x

Baruah, T. D. (2018). E-Learning as a Medium for Facilitating Learners' Support Services Under Open and Distance Learning: An Evaluative Study. Technology for Efficient Learner Support Services in Distance Education, 93-112. https://doi.org/10.1007/978-981-13-2300-3_5.

Butler, D. L., \& Sellbom, M. (2002). Barriers to adopting technology for teaching and learning. Education Quarter, 2, 22-28.

Danesi, M. (2014). Encyclopedia of Media and Communication. Reference Reviews, 28(3), 20-21. https://doi.org/10.1108/rr-10-2013-0257

Griffin, E. A., Ledbetter, A., \& Sparks, G. G. (2019). A first look at communication theory. /z-wcorg/.

Husson, F., Lê, S. \& Pagès, J. (2017). Exploratory Multivariate Analysis by Example Using R. Boca Raton: CRC Press.

Husson, F., Josse, J., Lê, S., \& Mazet, J. (2017). FactoMineR: Multivariate exploratory data analysis and data mining with $R$. R Package Version 1.35.

Katz, I., \& Macklin-Smith, A. (2013). Information and Communication Technology (ICT) Literacy: Integration and Assessment in Higher Education.

Keegan, D. (2005). Theoretical Principles of Distance Education. https://doi.org/10.4324/ 9780203983065 .

Kotler, P., \& Kevin Lane Keller. (2015). Marketing Management: Analysis, Planning, and Control (15th ed.). Pearson. https://www.amazon.com/Marketing-Management-15th-PhilipKotler/dp/0133856461/ref=tmm_hrd_swatch_0?_encoding=UTF8\&qid=\&sr=.

Lê, S., Josse, J., \& Husson, F. (2008). FactoMineR: An R Package for multivariate analysis. Journal of Statistical Software, 25(1), 1-18. doi: 10.18637/jss.v025.i01.

Margaryan, A., Littlejohn, A., \& Vojt, G. (2011). Are digital natives a myth or reality? University students' use of digital technologies. Computers \& Education, 56(2), 429-440. https://doi.org/10.1016/j.compedu.2010.09.004.

Marris, P., \& Thornham, S. (2005). Media studies: A reader. Edinburgh University Press; /z-wcorg/. 
Mohammadi, H. (2015). Investigating users' perspectives on e-learning: An integration of TAM and IS success model. Computers in Human Behavior, 45, 359-374. https://doi.org/10.1016/i.chb.2014.07.044.

Parkes, M., Stein, S., \& Reading, C. (2015). Student preparedness for university e-learning environments. The Internet and Higher Education, 25, 1-10. https://doi.org/10.1016/ j.iheduc.2014.10.002.

Prensky, M. (2001). Digital Natives, Digital Immigrants Part 1. On the Horizon, 9(5), 1-6. https://doi.org/10.1108/10748120110424816.

Wedemeyer, C. A. (1981). Learning at the back door. Reflections on non-traditional learning in the lifespan. Madison, Wl: University of Wisconsin. 


\section{LAMPIRAN}

Tabel L.7. Indikator Pertanyaan Deskriptif

\begin{tabular}{|c|c|c|c|c|c|}
\hline No. & Aspek & Kode & Pertanyaan & Kesiapan & Kepuasan \\
\hline 1 & Status & Stat & $\begin{array}{l}\text { Status Anda? (Dosen UT, Tutor Non UT, Mahasiswa UT, } \\
\text { Mahasiswa Non UT) }\end{array}$ & & \\
\hline 2 & Lokasi & Lok & $\begin{array}{l}\text { Lokasi Anda berada di lokasi Unit program Belajar Jarak Jauh } \\
\text { (UPBJJ) UT? (opsi jawaban lokasi UPBJJ UT) }\end{array}$ & & \\
\hline 3 & Akses & Aks & $\begin{array}{l}\text { Apakah Anda memiliki komputer dan akses internet yang } \\
\text { memadai? (Ya/Tidak) }\end{array}$ & $\sqrt{ }$ & \\
\hline 4 & Literasi & Lit & $\begin{array}{l}\text { Teknologi informasi membuat proses pembelajaran menjadi } \\
\text { lebih efektif ? (Ya/Tidak) }\end{array}$ & $\sqrt{ }$ & \\
\hline 5 & Keterampilan & $\mathrm{Kt1}$ & $\begin{array}{l}\text { Saya mampu mencari berbagai sumber informasi dengan } \\
\text { internet (Mahir Sekali, Mahir, Sedang, Kurang, Tidak mahir) }\end{array}$ & $\sqrt{ }$ & \\
\hline 6 & & $\mathrm{Kt} 2$ & $\begin{array}{l}\text { Saya mampu menggunakan berbagai aplikasi dalam komputer } \\
\text { untuk menyelesaikan tugas (Mahir Sekali, Mahir, Sedang, } \\
\text { Kurang, Tidak mahir) }\end{array}$ & $\sqrt{ }$ & \\
\hline 7 & Motivasi & Mo1 & $\begin{array}{l}\text { Apakah Anda lebih sering berinteraksi dalam pembelajaran } \\
\text { daring dibanding tatap muka? (Ya/Tidak) }\end{array}$ & $\sqrt{ }$ & $\sqrt{ }$ \\
\hline 8 & & Mo2 & $\begin{array}{l}\text { Apakah mahasiswa (tutor) cepat memberikan respon/umpan } \\
\text { balik pada pembelajaran daring? (Ya/Tidak) }\end{array}$ & & $\sqrt{ }$ \\
\hline
\end{tabular}

Tabel L.8. Indikator Pertanyaan Persepsi

\begin{tabular}{|c|c|c|c|c|c|}
\hline No. & Aspek & Kode & Pertanyaan & Kesiapan & Kepuasan \\
\hline 1 & Manfaat & M1 & $\begin{array}{l}\text { Pembelajaran daring bisa dilakukan kapan saja dan dimana } \\
\text { saja }\end{array}$ & & $\sqrt{ }$ \\
\hline 2 & & M2 & $\begin{array}{l}\text { Pembelajaran daring membuat proses pembelajaran lebih } \\
\text { terorganisasi }\end{array}$ & & $\sqrt{ }$ \\
\hline 3 & & M3 & Biaya untuk pembelajaran daring lebih murah & $\sqrt{ }$ & $\sqrt{ }$ \\
\hline 4 & Kendala & $\mathrm{K} 1$ & Tidak semua mahasiswa (dosen) memiliki akses internet & $\sqrt{ }$ & $\sqrt{ }$ \\
\hline 5 & & K2 & $\begin{array}{l}\text { Persiapan infrastruktur TIK untuk pembelajaran daring } \\
\text { memerlukan pembiayaan yang besar }\end{array}$ & $\sqrt{ }$ & $\sqrt{ }$ \\
\hline 6 & & K3 & Mahasiswa (dosen) tidak mampu menggunakan teknologi & $\sqrt{ }$ & \\
\hline 7 & & K4 & $\begin{array}{l}\text { Respon yang tertunda dari mahasiswa (tutor) membuat frustasi } \\
\text { tutor (mahasiswa) }\end{array}$ & & $\sqrt{ }$ \\
\hline 8 & $\begin{array}{l}\text { Faktor } \\
\text { Pendukung }\end{array}$ & $\mathrm{F} 1$ & $\begin{array}{l}\text { Kebijakan pemerintah sebagai faktor pendukung untuk } \\
\text { menggunakan pembelajaran daring }\end{array}$ & $\sqrt{ }$ & $\sqrt{ }$ \\
\hline 9 & & $\mathrm{~F} 2$ & $\begin{array}{l}\text { Generasi muda sekarang lebih menyukai pembelajaran jarak } \\
\text { jauh }\end{array}$ & & $\sqrt{ }$ \\
\hline 10 & & F3 & $\begin{array}{l}\text { Infrastruktur teknologi, informasi dan komunikasi mendukung } \\
\text { pembelajaran jarak jauh }\end{array}$ & $\sqrt{ }$ & $\sqrt{ }$ \\
\hline 11 & & $\mathrm{~F} 4$ & $\begin{array}{l}\text { Harga komputer yang semakin murah mendukung penggunaan } \\
\text { pembelajaran daring }\end{array}$ & $\sqrt{ }$ & $\sqrt{ }$ \\
\hline 12 & Prospek & $\mathrm{P} 1$ & $\begin{array}{l}\text { Sumber pembelajaran terbuka di Internet memberikan prospek } \\
\text { yang cerah untuk pembelajaran daring }\end{array}$ & & $\sqrt{ }$ \\
\hline 13 & & P2 & $\begin{array}{l}\text { Saya akan merekomendasikan pembelajaran daring ke } \\
\text { sesama mahasiswa (tutor) yang lain }\end{array}$ & & $\sqrt{ }$ \\
\hline 14 & Program & $P C$ & $\begin{array}{l}\text { Bagaimana pendapat Anda mengenai pembelajaran daring } \\
\text { saat terjadi pandemic COVID 19? }\end{array}$ & $\sqrt{ }$ & $\sqrt{ }$ \\
\hline
\end{tabular}


Tabel L.9. Distribusi Status dan Lokasi UPBJJ UT Partisipan

\begin{tabular}{|c|c|c|c|c|c|c|c|c|c|c|c|c|}
\hline \multirow[b]{2}{*}{ UPBJJ } & \multicolumn{2}{|c|}{ Dosen/Tutor } & \multicolumn{2}{|c|}{ Mahasis wa } & \multirow[b]{2}{*}{ Jumlah } & \multirow[b]{2}{*}{ No } & \multirow[b]{2}{*}{ UPBJJ } & \multicolumn{2}{|c|}{ Dosen/Tutor } & \multicolumn{2}{|c|}{ Mahasiswa } & \multirow[b]{2}{*}{ Jumlah } \\
\hline & UT & Non UT & UT & Non UT & & & & UT & Non UT & UT & Non UT & \\
\hline Banda Aceh & 0 & 1 & 122 & 0 & 123 & 22 & Denpasar & 2 & 1 & 306 & 5 & 314 \\
\hline Medan & 3 & 0 & 354 & 9 & 366 & 23 & Mataram & 1 & 2 & 117 & 0 & 120 \\
\hline Padang & 10 & 8 & 486 & 653 & 1.157 & 24 & Kupang & 3 & 3 & 246 & 1 & 253 \\
\hline Bengkulu & 2 & 3 & 140 & 8 & 153 & 25 & Banjarmasin & 0 & 0 & 0 & 0 & 0 \\
\hline Jambi & 0 & 1 & 195 & 25 & 221 & 26 & Pontianak & 0 & 0 & 216 & 2 & 218 \\
\hline Pekanbaru & 3 & 1 & 204 & 23 & 231 & 27 & Palangkaraya & 2 & 2 & 168 & 0 & 172 \\
\hline Pangkal Pinang & 3 & 0 & 200 & 0 & 203 & 28 & Samarinda & 1 & 1 & 339 & 0 & 341 \\
\hline Batam & 1 & 2 & 402 & 18 & 423 & 29 & Tarakan & 0 & 0 & 0 & 0 & 0 \\
\hline Palembang & 5 & 1 & 228 & 6 & 240 & 30 & Makasar & 1 & 1 & 118 & 5 & 125 \\
\hline Bandar Lampung & 4 & 2 & 284 & 2 & 292 & 31 & Majene & 0 & 0 & 70 & 0 & 70 \\
\hline Serang & 1 & 2 & 268 & 2 & 273 & 32 & Kendari & 2 & 0 & 59 & 0 & 61 \\
\hline DKI Jakarta & 21 & 10 & 1.466 & 14 & 1.511 & 33 & Palu & 1 & 0 & 65 & 2 & 68 \\
\hline Bogor & 2 & 5 & 647 & 3 & 657 & 34 & Gorontalo & 0 & 0 & 27 & 0 & 27 \\
\hline Bandung & 7 & 9 & 598 & 6 & 620 & 35 & Manado & 0 & 0 & 142 & 0 & 142 \\
\hline Semarang & 6 & 1 & 429 & 3 & 439 & 36 & Ambon & 3 & 1 & 71 & 2 & 77 \\
\hline Purwokerto & 2 & 0 & 331 & 1 & 334 & 37 & Ternate & 3 & 0 & 37 & 0 & 40 \\
\hline Yogyakarta & 8 & 3 & 475 & 4 & 490 & 38 & Sorong & 0 & 0 & 73 & 0 & 73 \\
\hline Surakarta & 4 & 2 & 257 & 8 & 271 & 39 & Jayapura & 0 & 1 & 84 & 1 & 86 \\
\hline Malang & 0 & 2 & 565 & 2 & 569 & 40 & Luar Negeri & 0 & 0 & 181 & 0 & 181 \\
\hline Jember & 0 & 2 & 348 & 2 & 352 & 41 & Lainnya & 11 & 6 & 1.222 & 74 & 1.313 \\
\hline Surabaya & 4 & 6 & 688 & 3 & 701 & Jum & lah & 116 & 79 & 12.228 & 884 & 13.307 \\
\hline
\end{tabular}

\section{Keterangan :}

- Jumlah partisipan 13.307 orang, $91,9 \%$ adalah mahasiswa UT, 6,6\% mahasiswa non UT, dan 1,5\% adalah dosen/tutor UT atau non UT.

Dosen/tutor

- Jumlah partisipan dosen/tutor 195 orang, 59,5\% dosen UT dan 40,5\% tutor non UT.

- Partisipan wilayah Sumatera $25,6 \%$ dan Jawa $49,7 \%$.

- Partisipan di Sumatera, $15,9 \%$ dosen UT dan $9,7 \%$ tutor non UT.

- Partisipan di Jawa, 28,2\% dosen UT dan 21,5\% tutor non UT.

Mahasiswa

- Partisipan mahasiswa 13.112 orang, 93,3\% mahasiswa UT, dan 6,7 \% mahasiswa non UT.

- Partisipan wilayah Sumatera 25,6\%, Jawa 49,7\%, Bali/NT 5,1\%, Kalimantan 5,5\%, Sulawesi 3,7\%, Maluku/Papua 2,0\%, dan Luar Negeri 1,4\%.

- $\quad$ Partisipan di Sumatera, $19,9 \%$ mahasiswa UT dan 5,7\% mahasiswa non UT.

- Jumlah partisipan di Jawa, 46,3\% mahasiswa UT dan 0,4\% mahasiswa non UT. 
Tabel L.10. Distribusi Deskriptif Partisipan

\begin{tabular}{|c|c|c|c|c|}
\hline \multirow{2}{*}{$\begin{array}{l}\text { Kode } \\
\text { Aks }\end{array}$} & \multirow{2}{*}{$\begin{array}{l}\text { Pertanyaan } \\
\text { Apakah Anda memiliki komputer dan akses internet yang memadai? }\end{array}$} & \multicolumn{2}{|c|}{ Frekuensi } & \multirow{2}{*}{$\%$} \\
\hline & & $Y a$ & 10.888 & \\
\hline & & Tidak & 2.419 & 18,2 \\
\hline \multirow[t]{2}{*}{ Lit } & Teknologi informasi membuat proses pembelajaran menjadi lebih efektif? & $Y a$ & 12.422 & 93,3 \\
\hline & & Tidak & 885 & 6,7 \\
\hline \multirow[t]{5}{*}{ Kt1 } & Saya mampu mencari berbagai sumber informasi dengan internet & Mahir Sekali & 3.639 & 27,3 \\
\hline & & Mahir & 5.699 & 42,8 \\
\hline & & Sedang & 3.303 & 24,8 \\
\hline & & Kurang & 403 & 3,0 \\
\hline & & Tidak Mahir & 263 & 2,0 \\
\hline \multirow[t]{5}{*}{ Kt2 } & Saya mampu menggunakan berbagai aplikasi dalam komputer & Mahir Sekali & 3.011 & 22,6 \\
\hline & untuk menyelesaikan tugas & Mahir & 5.368 & 40,3 \\
\hline & & Sedang & 3.824 & 28,7 \\
\hline & & Kurang & 706 & 5,3 \\
\hline & & Tidak Mahir & 398 & 3,0 \\
\hline \multirow[t]{2}{*}{ Mo1 } & Apakah Anda lebih sering berinteraksi dalam pembelajaran daring & $Y a$ & 9.636 & 72,4 \\
\hline & dibanding tatap muka? & Tidak & 3.671 & 27,6 \\
\hline \multirow[t]{2}{*}{ Mo2 } & Apakah mahasiswa (tutor) cepat memberikan respon/umpan balik & $Y a$ & 9.372 & 70,4 \\
\hline & pada pembelajaran daring? & Tidak & 3.935 & 29,6 \\
\hline
\end{tabular}

\section{Keterangan:}

1) Pada aspek akses/literasi (P01-P04), akses partisipan kepada informasi cukup bervariasi, $81,8 \%$ partisipan mempunyai akses informasi yang memadai, dan selainnya $(18,2 \%)$ tidak memiliki akses yang memadai (tidak memiliki komputer atau jaringan yang memadai). Literasi informasi partisipan umumnya hampir seragam, 93,3\% menyatakan teknologi informasi membuat proses pembelajaran menjadi lebih efektif.

2) Pada aspek keterampilan (P03-P04), keterampilan teknologi informasi partisipan bervariasi atas tiga kelompok : sangat mahir $\pm 30 \%$, mahir $( \pm 40 \%)$, atau sedang/kurang/tidak mahir $( \pm 30 \%)$ dalam mencari sumber informasi atau menggunakan aplikasi komputer.

3) Pada aspek pengalaman motivasi dalam pembelajaran daring (P05-P06), motivasi partisipan bervariasi atas sekitar $70 \%$ mahasiswa/tutor menyatakan mereka lebih sering berinteraksi atau menilai tutor/mahasiswa memberikan umpan balik dalam pembelajaran daring, dan 30\% selainnya. 


\section{INDEKS JURNAL PENDIDIKAN TERBUKA DAN JARAK JAUH TAHUN 2019}

aksesibilitas tutorial online, 33

ASEAN collaboration, 1, 3

asynchronous communication, 32

Autonomous Learning, 10

basic diseases, 39

COVID-19, 92, 93

Design Online Learning Model, 17

Distance Education Services, 25

educational diplomacy, 1

Effectiveness, 17

face to face tutorial, 80

health information \& knowledge, 39

indeks kepuasan masyarakat, 80, 83, 84, 86, 87, 91

information communication technology, 39

komunikasi asinkronus, 33

meta analisis, 32, 33, 35

meta-analysis, 32

MOOC, $1,3,4,5,6,7$

OER, 6, 60, 65, 68, 69, 70, 71, 72, 73, 74, 75, 76, 77, 78

Online Learning, 8, 10, 24, 78

online learning readiness, 92

online tutorial accessibility, 32

online tutorials, 32, 52, 56, 57, 59, 60

online tutorials as a tool, 32

open and distance learning, 2, 52, 53, 61, 65, 66

Open educational resources, 68, 70

Open University, 52, 53, 54, 57, 63, 66

operational system, 52,53

pandemic, 92, 99, 100, 109

Pendidikan Kejuruan, 17, 24

people-to-people engagement, 1, 3

perceptions, 3, 68, 69, 71, 74, 75, 78, 92

Pokjar Management, 25

public satisfaction index, 80

quality assurance, 52, 53, 55, 61, 66, 67

questionnaire, 43, 44, 68, 71

Role, 25

satisfaction, 73, 76, 92

Task-Based Approach, 10

tutorial online , 7, 10, 11, 12, 14, 15, 16, 32, 33, 34, 36, 52

tutorial online sebagai alat, 33

Universitas Terbuka Regional Office Bengkulu, 80 


\section{INDEKS PENULIS JURNAL PENDIDIKAN TERBUKA DAN JARAK JAUH \\ TAHUN 2019}

Adhi Susilo, 92

Aminudin Zuhairi, 52

Andre Iman S, 68

Arifah Bintarti, 32

Athiyah Salwa, 10

Deddy A. Suhardi, 92

Dwi Kristanti, 80

Eha Saleha, 25

Habib Ur Rahman, 39

Mani Festati Broto, 1

Moiz Uddin Ahmed, 39

Nazir Ahmed Sangi, 39

Ojat Darojat, 92

Sri Suharmini Wahyuningsih, 32

Syaiputra Wahyuda Meisa Diningrat, 17

Tri Darmayanti, 32 
INDEKS PENYUNTING JURNAL PENDIDIKAN TERBUKA DAN JARAK JAUH TAHUN 2019

\author{
Daryono \\ Purwanto \\ Oos Anwas \\ Tri Darmayanti \\ Asmawi Zainul \\ Maximus Gorky Sembiring \\ Muhammad Husni Arifin \\ M. Atwi Suparman \\ Adhi Susilo \\ Herman \\ Widyasari \\ Santi Dewiki \\ Mohamad Toha \\ Ida Malati Sadjati
}

